\title{
The Swiss Way of Presenting the Governments' Financial Statements
}

\author{
Nils Soguel
}

\subsection{INTRODUCTION}

The goal of this chapter is to give the reader the keys to understanding the financial statements and budget plans as they are prepared and presented by Swiss governments at the three different levels. ${ }^{1}$ This means presenting the main statements and their purpose, as well as how the statements are interrelated.

In Switzerland, as elsewhere, financial statements are a major element of governmental information systems and must be organized so as to respond to the various expectations interested parties have of the government. These expectations have evolved over time as the country's internal

\footnotetext{
${ }^{1}$ Here we use 'government' in the way it is used by the International Monetary Fund (IMF 2014): a unique legal entity established by political processes that has legislative, judicial, or executive authority over other institutional units (households, corporations, and non-profit institutions) within a given area (p. 14). Therefore, a government is an organization that includes several branches: a legislature (parliament), an executive branch with its administration, and a judiciary, either at the federal, the cantonal, or the municipal level.
}

The author is grateful to Evelyn Munier for her contribution to this chapter.

N. Soguel $(\bowtie)$

IDHEAP, University of Lausanne, Lausanne, Switzerland

e-mail: nils.soguel@unil.ch

(C) The Author(s) 2019

A. Ladner et al. (eds.), Swiss Public Administration, Governance and Public Management, https://doi.org/10.1007/978-3-319-92381-9_15 
institutions have transformed, as well as due to technical, accounting and computing changes.

Therefore, the two following sections retrace the historical evolution of public accounting in Switzerland and the requirements for the accounting model. Section 15.4 presents the overarching structure of financial statements, while Sect. 15.5 is dedicated to two specific features of financial reporting: internal service pricing (ISP) and political finessing.

\subsection{The History of Switzerland's Governmental}

\section{Accounting System}

The history of governmental accounting in Switzerland is marked by repeated attempts to harmonize policies both horizontally-between cantons-and vertically-between municipalities, cantons and the Confederation. The first attempts at harmonization date from the nineteenth century.

The federalist organization of Switzerland for many years doomed these attempts to failure. Each canton sets out, in its own Financial Management Act of Parliament (FMAP), how it will organize itself financially, including what system it will use to prepare and present its financial statements. This explains why, until the mid-1960s, virtually every canton used a different system. Some cantons, like most Swiss municipalities, used a system inspired by the private sector, namely double-entry accounting with an income statement and a balance sheet. But other cantons used cash-basis accounting, like the central government.

Nonetheless, the modernization of the state slowly increased the need for harmonization of accounting systems. This came out of increased expectations in transparency, comparability and accountability. In a federalist system like Switzerland's, harmonization is particularly necessary to provide the consistent information required by the fiscal equalization system. It is also necessary to guarantee fiscal policy coordination.

It still took until the late 1970s for movement toward harmonization both between the cantons and the municipalities to begin. This movement was initiated by the intercantonal Conference of the Cantonal Finance Ministers (CFM) (Konferenz der kantonalen Finanzdirektorinnen und Finanzdirektoren, Conférence des directrices et directeurs cantonaux des finances). This Conference brings ministers together with the goal of coordinating the cantonal policy in fiscal matters when cantons decide that coordination is necessary. Nevertheless, the CFM cannot force the can- 
tons to act; it can only formulate recommendations. Thus, it was only able to recommend the cantons to implement, for themselves and for their municipalities, the first Harmonized Accounting Model (HAMl) (see CFM 1981). The heart of HAMI consisted of a detailed chart of accounts to be used both for the budget plan (beginning-of-the-year) and for the financial statements (end-of-the-year), but also for the multi-year financial plan. The chart of accounts is designed around a statement of financial performance, a statement of capital expenditure, a statement of financial position, and an embryonic cash flow statement. ${ }^{2}$

It would only be by the mid-1990s that most cantons and municipalities took the first step toward harmonization. However, they applied the HAMl in highly variable ways (and rigor), while the central government continued to use a cash-based accounting system.

Eventually the central government's position became more and more untenable. Several factors finally forced it, in 2007, to switch to an accrual accounting system in order to provide a more faithful representation of its financial condition. This change came about partly in response to New Public Management (NPM) pressures, but it was also due to the development of the International Public Sector Accounting Standards (IPSASs), to the need for more robust financial statistics at the national and international levels, and for lenders to be more readily able to understand the central governments' financial statements.

Certain cantons were also confronted with the same demands as the Confederation. This was particularly true for Geneva and Zurich, cantons frequently present on the capital market due to the size of their debt burdens. In response to their particular needs, the CFM created a secondgeneration Harmonized Accounting Model (HAM2; see CFM 2008). The heart of HAM2 remained the chart of accounts, but in the modified or evolved form. The HAM2 also proposes 20 standards that are essentially recommendations since the cantons remain free to include them or not into their FMAPs.

The HAM2 is an evolution of the HAMl which is compatible with the 2007 central government's accounting system and with the IPSASs. It offers governments, in ten or so cases, alternative accounting policies (e.g. linear or degressive depreciation; the possibility but not the obligation to

\footnotetext{
${ }^{2}$ Note that the terminology used in the text is that provided by the IPSASs (International Public Sector Accounting Standards). When necessary the German and French equivalent, as used in the Swiss governments, is given.
} 
restate their administrative assets when introducing the HAM2; and the opportunity that their FMAP provides for the possibility of some forms of political finessing when preparing the financial statements). With these alternatives, all cantons found their way: both those that want their financial statements to provide a faithful representation of economic and other phenomena, ${ }^{3}$ and those cantons adept at a more political approach to public finance which place a much greater emphasis on the prudence concept.

When it published its 2008 Manual, the CFM recommended the cantons implement the HAM2 within a maximum period of ten years. By 2018, all cantons will have introduced this new model, and the municipalities, will do so by 2021 or 2022 . So far, the proposed chart of accounts has been uniformly implemented. However, the cantons do take advantage of the alternatives offered by HAM2. As a result, policies are becoming harmonized, but remain far from uniform (Soguel and Munier 2017).

\subsection{ReQuirements For the Accounting Model and Principles for the Recognition of Transactions}

Both HAMl (1981) and HAM2 (2008) were designed to serve various functions as follows:

- Make it possible to implement the legal framework for financial management (Finanzrecht, Droit budgétaire) and specifically to regulate appropriations and the granting of credits (Kreditrecht, Droit des crédits)

- Serve as the basis for financial management, notably to establish and control financial plans, service provision agreements, fiscal rules, or financial indicators

- Link performance-focused and fiscal management in order to stimulate the managerial conduct within and between the various governmental units

\footnotetext{
${ }^{3}$ As stated in the IPSASB Conceptual Framework (2015, p. 49), 'faithful representation is attained when the depiction of the phenomenon is complete, neutral, and free from material error. Information that faithfully represents an economic or other phenomenon depicts the substance of the underlying transaction, other event, activity or circumstance — - which is not necessarily always the same as its legal form'.
} 
- Enable macroeconomic analysis so as to be able to implement a sensible fiscal policy

- Support the creation of financial statistics

- Facilitate the protection of creditor interests

To fulfill these functions and to ensure that the information provided in the financial statements are as faithful as possible, the HAM2 explicitly outlines several basic rules:

- accrual principle (Periodenabgrenzung; Comptabilité d'exercice);

- going concern principle (Fortfübrung; Continuité);

- materiality principle (Wesentlichkeit; Importance);

- gross recognition principle (Bruttodarstellung; Produit brut);

- reliability principle (Zuverlüssigkeit; Fiabilité);

- comparability and consistency principles (Vergleichbarkeit und Stetigkeit; Comparabilité et permanence des méthodes);

- understandability principle (Verständlichkeit; Clareté). This last principle is particularly important in a system like Switzerland's, in which parliamentarians are part-time, and in which direct democracy requires that citizens understand their governments' financial condition.

\subsection{Overarching Structure of the Financial STATEMENTS}

The financial statements give a structured representation of a government's financial condition. They provide information about revenue and expenses, current and capital expenditure and receipts, cash flow, and assets and liabilities. The set of financial statements recommended by the HAM2 comprises a statement of financial performance (SoPERF), of capital expenditure (SoCAPEX), of financial position (SoPOS), and of cash flow, along with notes providing additional financial and non-financial explanations.

Taken together, the SoPERF and the SoCAPEX form the 'administrative statement' in HAMl. This designation demonstrates that all current or capital expenditure granted by a budgetary appropriation must be recorded in this dedicated group of statements. It also demonstrates that all spending items recorded in the 'administrative statement' are accordingly submitted to the political supervision of the council of the executive branch and of the Parliament. 


\subsubsection{Statement of Financial Performance}

The SoPERF (i.e. income statement, Erfolgsrechnung, Compte de résultats) provides information about the government's operating costs and the degree to which revenue covers the charges. It indicates whether revenue-notably tax revenue-is sufficient to cover the costs of the services provided. Ideally, the income statement must be balanced, if not annually, then at least in the medium term.

The SoPERF also lists the budgetary appropriations for current expenditures granted by a Parliament when it approves a budget plan. In the (end-of-the-year) financial statements, this makes it possible to control the level of use of these credits.

This makes the SoPERF a key element of the government's financial management system. Indeed, its total is targeted by the fiscal rules in all cantons and in most municipalities, which is why SoPERF is usually located at the beginning of the report on the budget plan and the financial statements. Furthermore, in both documents most of the pages are dedicated to the SoPERF.

The HAM2 introduced a three-level structure in the SoPERF, replacing what had been only a single level statement (see Fig. 15.1).

The first level isolates operating revenue and operating expenses to show the operating result (Ergebnis aus betrieblicher Tätigkeit; Résultat d'exploitation). Operating revenue includes tax revenue, royalties and

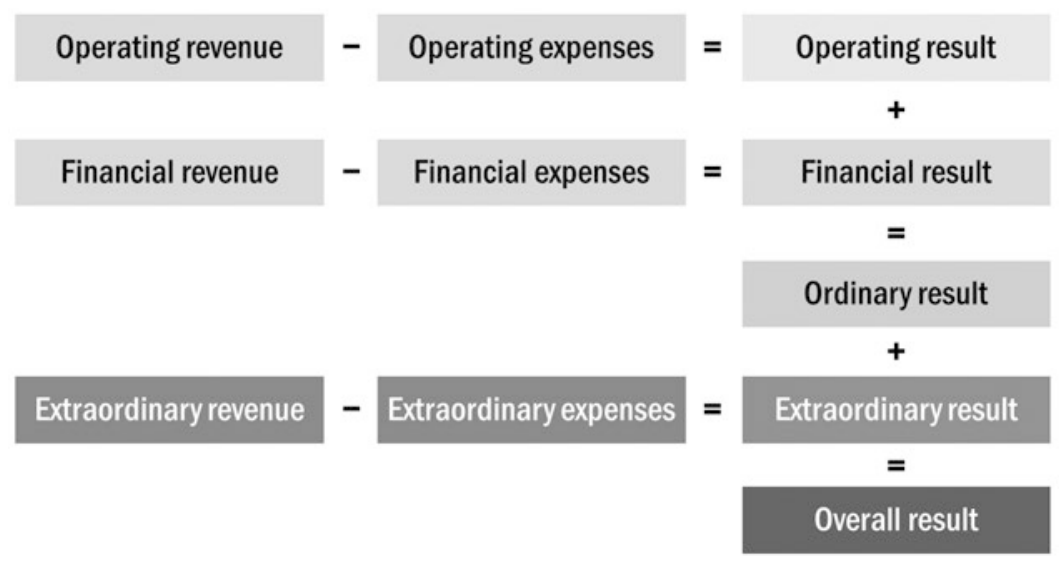

Fig. 15.1 The three-step statement of financial performance 
concessions, revenue from exchange transactions, or transfer revenue. Operating expenses include notably personnel expenses, purchases of goods and services, depreciations of administrative assets, or transfer expenses.

The second level isolates financial revenue (e.g. interest income) and expenses (e.g. interest expense) to show the financial result (Ergebnis aus Finanzierung; Résultat financier). Together the operating result and the financial result form the ordinary result (Operatives Ergebnis; Résultat opérationnel).

The third level isolates extraordinary revenue and extraordinary expenses to show the extraordinary result (Ausserordentliches Ergebnis; Résultat extraordinaire). Extraordinary items correspond to unpredictable and beyond-anyone's-control events, like natural catastrophes. They also include various political finessing operations (see below).

The overall result is obtained by summing the ordinary result and the extraordinary result, or in other words, shows the difference between all revenues and all expenses. A surplus increases the net worth in the SoPOS, while a deficit reduces the net worth. The ordinary result is that which best reflects financial performance since it excludes the extraordinary elements and those relevant to political finessing. ${ }^{4}$

Revenue and expenses must be registered and classified according to their nature, meaning following an economic classification. In addition, they must be classified by functional purpose, such as health, education or social protection. Both classifications are standardized in the HAM2 chart of accounts, easing inter-government comparisons. The functional classification is compatible with the UN's Classification of Functions of Government (COFOG). Governments may use a third classification reflecting how their organization is designed, which is essential for monitoring how budgetary appropriations are used by various ministries or departments. However, since governmental organizations differ, this classification cannot be standardized.

${ }^{4}$ IPSAS do not explicitly preclude the presentation of items as extraordinary items (IPSASB 2015 , p. 206). However, given the IPSAS requirement for faithful representation, the IPSAS understanding of the concept of extraordinary expenses or revenues does not encompass political finessing. 


\subsubsection{Statement of Capital Expenditure}

The SoCAPEX (Investitionsrechnung, Compte des investissements) is a particular characteristic of the HAM. It comes in addition to the statement required by the IPSASs and is nonetheless compatible with them.

Any expenditure that creates an asset used by the government over several years in providing legally required public services must be recorded in the SoCAPEX, together with the corresponding receipts (e.g. capital grants). Such assets are labeled administrative assets (Verwaltungsvermögen, Patrimoine administratif).

Some expenditures do not create administrative assets. For instance, the government may use an asset as a yield-producing investment vehicle (e.g. by-to-let properties or securities; Geldanlage, Placements). Such yield-producing expenditure creates non-administrative assets (Finanzvermögen, Patrimoine financier). These assets are directly recorded in the SoPOS. All other expenditures are current expenditures and do not create any assets. These latter are registered in the SoPERF instead.

The distinction between the three kinds of expenditures (current, capital, and yield-producing) is important from a legal perspective. Current and capital expenditures depend on budgetary appropriation and thus on parliamentary decisions. Yield-producing expenditures, on the other hand, are in principle the prerogative of the executive branch council and are exempt from parliamentary approval.

In this way, the SoCAPEX provides information on the government's equipment and infrastructure efforts. On average, capital expenditures are equivalent to about $10 \%$ of current expenditures. The balance of the SoCAPEX shows net capital expenditures after deducting capital receipts. Expenditures are usually larger than receipts except when grants are not received in the same accounting period when expenditure are recognized. When closing the account, the administrative assets created are recognized as such in the SoPOS.

Capital expenditures can take various forms. They include expenditures to buy, build, or improve tangible and intangible fixed assets, like land, civil engineering work, building construction, plant and equipment, software or patents. They also include contributions or loans provided to other entities or governments, which are meant to create assets for the provision of public services required by law. 


\subsubsection{Statement of Financial Position}

The SoPOS (Bilanz, Bilan) is less important in the financial statements of Swiss governments than it is in the statements of private companies. In the private sector it comes first, but in the public sector, it typically comes at the end of the financial statements. Nevertheless, the purpose is similar: the SoPOS offers an inventory of assets and shows to what extent they have been financed by borrowing (i.e. liabilities) or through equity (i.e. accumulated surpluses). The statement is a static picture of the financial condition, typically on 1 January or 31 December. It is thus unlike the other statements, which give information about flows throughout the year showing the flow of expenses and revenue, of capital expenditure and receipts, and of cash.

In the inventory, the HAM2 distinguishes between administrative assets stemming from capital expenditure and non-administrative assets stemming from yield-producing investment vehicles. The distinction is not required by the IPSASs nor is it encountered in the private sector. It is based upon the alienability principle, a notion introduced in HAMl but no longer included in HAM2. Besides being justified by the regulation of appropriations, the distinction makes it possible to figure out which assets may not be sold (e.g. administrative assets without which a legally required public service could not be provided) and which assets can be sold without endangering existing public services (i.e. non-administrative assets).

Non-administrative assets are split between current and fixed assets (Fig. 15.2). The HAM2 requires that they be measured and reported at their fair value and, if available, at their market value. By providing governments with a common measurement basis and a unified principle to separate them from administrative assets, the HAM2 dramatically increases the comparability of net debt between governments. The government's net debt is defined as the difference between liabilities and non-administrative assets, since the latter can be sold freely and converted into cash to pay back the debt. Although a comparison of Swiss governments based on net debt is thereby made possible, this is not the case between countries, which is why international comparisons are almost always based on gross debt. This approach involves a risk of bias. Indeed, a variable part of the public debt can be contracted to finance yield-producing investment vehicles. Yet contracting a debt for this reason should be analyzed from a fundamentally different perspective compared to when the debt is contracted to finance administrative assets that the law forbids from selling. 

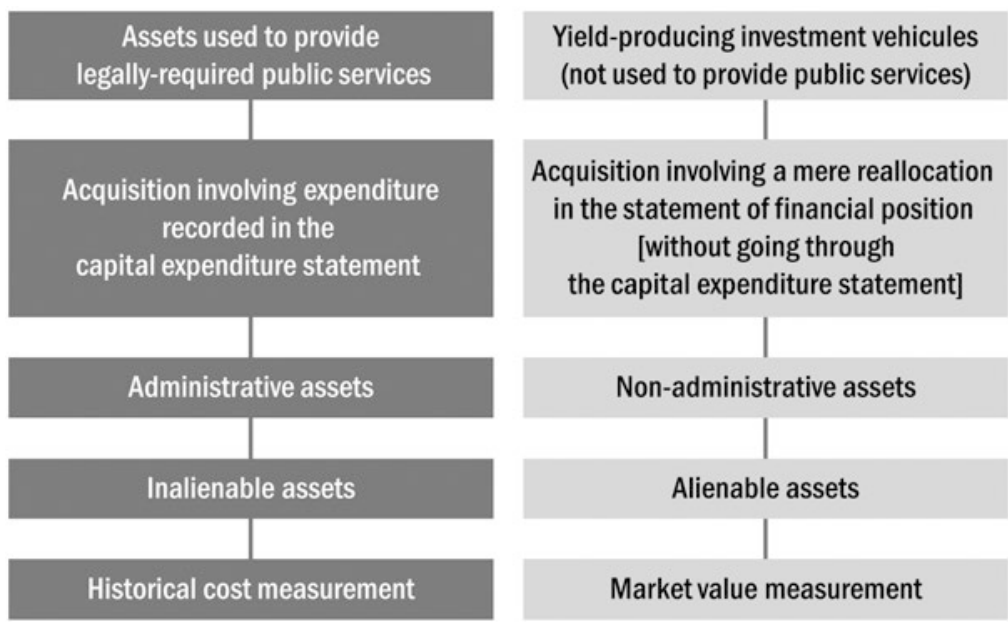

Fig. 15.2 Assets in the statement of financial position

In terms of administrative assets, HAM2 stipulates that they should be measured and reported at their depreciated historical cost, meaning at the cost incurred upon their acquisition and subsequent enhancement less a reduction for depreciation to date. Year after year, over their useful life, their reported amount is gradually reduced by recognizing the depreciation that represents their wear and tear and obsolescence. For each accounting period, depreciation is recorded in the SoPERF.

The liability side is structured in the same way as in the private sector, with a subdivision between liabilities and net worth (Fig. 15.3). Liabilities are measured at their fair value and classified according to their nature and time period (short or long term). Net worth is split between various components, including the accumulated annual surpluses and deficits and various types of reserves (dedicated to the financing of future capital projects or future fiscal policy measures).

\subsubsection{Interactions Between the Three Statements: Financial Performance, Capital Expenditure and Financial Position}

The amounts presented in the SoPOS vary between the beginning and the end of the year because of transactions recognized in the SoCAPEX and in the SoPERF. As shown in Fig. 15.4, capital expenditures increase the 

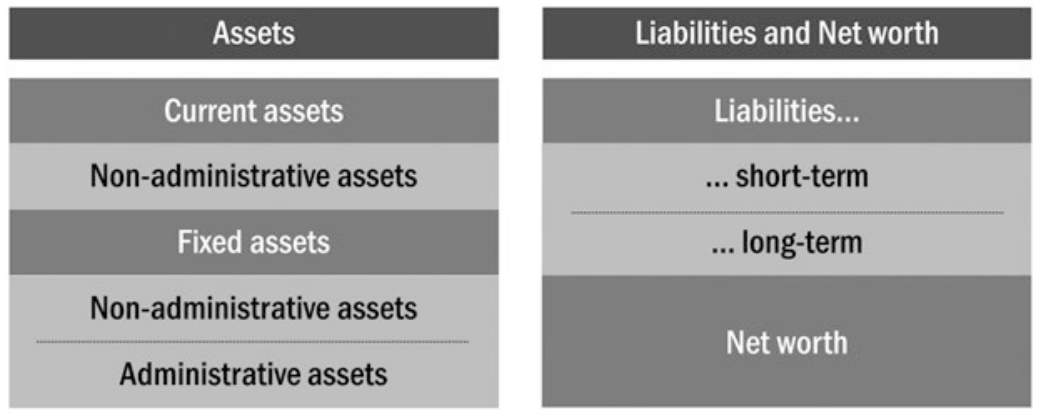

Fig. 15.3 Structure of the statement of financial position

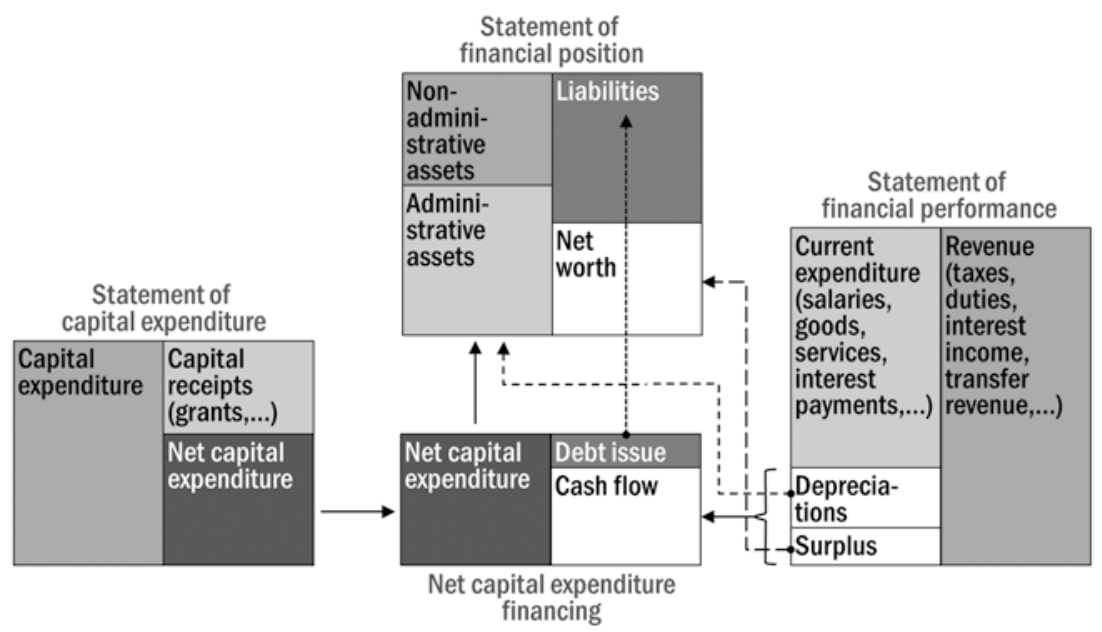

Fig. 15.4 Interactions between the statements and the simplified cash flow statement

overall amount of the administrative assets, while depreciations reduce this amount. The net worth increases or decreases depending on whether the SoPERF reports a surplus or a deficit.

Figure 15.4 also shows the embryonic cash flow statement introduced by the HAMI. Net capital expenditure, the cash drain from the difference between capital expenditure and receipts, may be financed either with the cash flow originating in the transactions recorded in the SoPERF, or by 
issuing debt. To simplify, this cash flow is considered equal to the surplus (or the deficit) added to the depreciations, or in other words, to the difference between cash flow generated by revenue and cash drain generated by expense. It is the difference between current receipts and expenditures. A depreciation expense typically does not involve cash. Instead, it reduces the surplus without reducing the cash account in the SoPOS. Thus the difference between expense and current expenditure is mainly due to depreciation.

There are other scenarios. In case the cash flow is larger than net capital expenditure, the government pays back its debt (liabilities). In case the deficit is larger than the depreciations, the cash flow becomes negative and debt must be issued not only to finance capital expenditure but also to cover current expenditure.

\subsubsection{Cash Flow Statement}

The HAM2 introduced a fully fledged cash flow statement (Geldflussrechnung, Tableau des flux de trésorerie), providing information on how the government raises the cash required to finance its activities over the reporting period and how this cash was used. The information is classified according to the various activities, following the IPSASs, and thus listing operating, investing and financing activities. The only specifically Swiss element here is that within investment activities, a distinction is made between the activities triggered by capital expenditure and those triggered by yield-producing investments. In the end, the statement sheds light on the reasons for changes in cash (and cash equivalents) between the beginning and the end of the year, as shown in the SoPOS.

\subsubsection{Notes to the Financial Statements}

The notes (Anhang, Annexe) give information about the accounting policy. A government whose financial statements do not comply with all HAM2 requirements must explicitly mention in which manner they diverge. The notes must also provide additional information regarding changes in equity, provision, equity participation, guarantees, and tangible assets. Finally, the notes must include any additional information explaining the development of net assets, financial position, and the result of operations. The requirements regarding the content of the notes are similar to those contained in the IPSASs. 


\subsection{Two Specific Features}

\subsubsection{Internal Service Pricing}

Internal service pricing (ISP) was heralded as an important feature of the HAMl. The aim was to explicitly promote a cost-based way of thinking. The equivalent of the service is credited as revenue in the department providing the service; it is debited as an expense in the department receiving the service. Such ISP entries are purely book entries and as such neither generate nor drain cash.

ISP was implicitly expected to raise the level of cost transparency in public management, in order to increase public managers' accountability for the costs they incur and to enhance competition between internal suppliers and external competitors. So far empirical evidence shows that the target was not met at the cantonal level: the volume of ISP does not significantly and negatively correlate with that of government expenditure (Clémenceau and Soguel 2014).

This may have been because the ISP amounts were too small to influence management practices; on average among cantons, they amount to only $6 \%$ of total expenditures. The ISP is mainly used in areas where it is necessary to decide over the price to be paid by external users, meaning where the full cost must be charged to citizens (fees) or shared with other jurisdictions (transfers). One can also legitimately ask whether ISP reflects a faithful view of internally provided services. ISP is mainly the result of allocating centrally borne costs (depreciation, interest payments, information technology (IT), etc.), and so most of the costs allocated as ISP are only marginally the result of a rational decision over the goods and services to be internally purchased. As a result, they may not reflect a selfdefined consumption, and public managers may even have less flexibility to cut internally charged services. This suggests that the lack of impact of the ISPs could mainly be due to how they are computed.

\subsubsection{Political Finessing}

Although the FMAP differs from canton to canton, all 26 FMAPs share a common and conservative fiscal stance. Thus, it does not come as a surprise that the Conference of CFM explicitly embedded several modes of political finessing into the HAM2. Many cantons have decided to adopt one or more of these possibilities into their own FMAPs. These are 
meant to artificially inflate expenses in the SoPERF, and include 'cookiejar' reserves, reporting capital expenditure as operating expenditures, pre-funding, and 'additional depreciation charges'.

This last goes beyond depreciation charges that arise from actual wear and tear or the obsolescence of administrative assets. Depending on the canton and year, such 'additional depreciation charges' can amount to more than $2 \%$ of 'true' expenses. Managing depreciations seems to produce a significant and positive impact on a cantons' future financial performance (Clémenceau and Soguel 2018). Political finessing fosters the flexibility to ensure structural surpluses, prevent structural deficits, and facilitate meeting fiscal rule requirements. Admittedly, these operations must be reported as extraordinary expenses and thus do not impact the ordinary result. Nevertheless, they have an impact on the overall result and prevent 'true' performance from being reported with full transparency. Ultimately, when translating the HAM2 into their FMAP, cantons must make a tradeoff between conflicting wishes for fiscal soundness and faithful financial reporting.

\subsection{Conclusion}

The downsides concerning the possibilities of political finessing and the fact that ISP is not better used should not make us forget that Swiss governments have achieved a high standard of quality in their financial statements. The central government is close to fulfilling all the requirements formulated in the IPSASs. This also holds for several cantons, including Basel-Stadt, Bern, Geneva, Lucerne, and Zurich. Other cantons and municipalities are gradually improving the quality of the information provided in their financial statements.

This is remarkable when considering the great autonomy the cantons have in this area and remarkable in the absence of legal strictures obligating cantonal governments to use the proposed harmonized accounting model. Improvements are also being made possible by the Swiss Public Sector Financial Reporting Advisory Committee, a committee established by the intercantonal Conference of the CFM. It has become a de facto standard-setter for how accounting is conducted in the three tiers of Swiss government. 


\section{REFERENCES}

CFM (Conference of Cantonal Finance Ministers/Konferenz der kantonalen Finanzdirektoren). (1981). Government accounting manual/Handbuch des Rechnungswesens der öffentlichen Haushalte [HAMI]. Bern: Verlag Paul Haupt.

CFM (Conference of Cantonal Finance Ministers/Konferenz der kantonalen Finanzdirektorinnen und Finanzdirektoren). (2008). Manual-Harmonised accounting model for cantons and municipalities/Handbuch - Harmonisiertes Rechnungsmodell für die Kantone und Gemeinden [HAM2]. Bern: CFM.

Clémenceau, M., \& Soguel, N. (2014). Impact des imputations internes sur le niveau des déficits publics: Le cas des cantons suisses. In M. Djouldem, G. Tellier, \& C. de Visscher (Eds.), Les réformes des finances publiques: Enjeux politiques et gestionnaires (pp. 187-216). Bruxelles: Ed. Bruylant.

Clémenceau, M., \& Soguel, N. (2018). How does depreciations management affect subsequent fiscal performance? The case of the Swiss Cantons. Swiss Journal of Economics and Statistics, 154(7), 1-13.

IMF (International Monetary Fund) Statistics Department. (2014). Government finance statistics manual 2014. Washington, DC: International Monetary Fund. IPSASB (International Public Sector Accounting Standards Board). (2015). Handbook of international public sector accounting pronouncements. New York: International Federation of Accountants-IFAC.

Soguel, N., \& Munier, E. (2017). Harmonisierung der Rechnungslegung in den Kantonen und Gemeinden. Rechnungswesen \& Controlling, 2, 2-4.

Open Access This chapter is licensed under the terms of the Creative Commons Attribution 4.0 International License (http://creativecommons.org/licenses/ by $/ 4.0 /$ ), which permits use, sharing, adaptation, distribution and reproduction in any medium or format, as long as you give appropriate credit to the original author(s) and the source, provide a link to the Creative Commons license and indicate if changes were made.

The images or other third party material in this chapter are included in the chapter's Creative Commons license, unless indicated otherwise in a credit line to the material. If material is not included in the chapter's Creative Commons license and your intended use is not permitted by statutory regulation or exceeds the permitted use, you will need to obtain permission directly from the copyright holder.

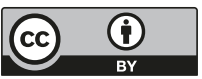

